\title{
ANTHROPOGENIC DISTURBANCES AND CONSERVATION OF COASTAL ENVIRONMENTS IN AN OCEANIC ARCHIPELAGO
}

\author{
Juan D. Delgad0 ${ }^{1}$, Rodrigo Riera ${ }^{2}$
}

ABSTRACT: Oceanic islands are biotically fragile environments prone to suffer irreversible anthropogenic disturbances. The growth of the human population and the intensive occupation of the coastline are the cause of great ecological pressure on global insular coastal ecosystems. We review the current situation and future scenarios on a paradigmatic oceanic archipelago (Canary Islands, NE Atlantic 0cean), as a case study of the human footprint on marine coastal communities. The role of humans is pivotal, as we directly affect patterns of coastal occupation, pollution, invasive species or fishing. Here we synthesize the information that describes the current situation of the coastal ecosystems of the Canary Islands, indicating the main sources of environmental conflict and impacts. In addition, we review the state of the most relevant or threatened habitats and the taxonomic groups as actors of the main disturbances in the coastal ecosystems of the archipelago. We propose future general scenarios about expected changes, and foreseeable interactions that could occur to transform the coastal environments of the islands, in order to indicate areas susceptible to improvement for the conservation of these ecosystems. Integrative coastal actions are urgently needed for sustainable future scenarios to oppose deleterious trends such as tropicalization, fisheries collapse and extensive coastal degradation due to urbanization and infrastructure construction.

Keywords: Coastal development, overfishing, overpopulation, human-induced disturbance, introduced species, islands, oceanic archipelago.

RESUM0: As ilhas oceânicas são ambientes bioticamente frágeis e sujeitos a distúrbios antropogénicos irreversíveis. 0 crescimento da população humana e a ocupação intensiva do litoral são a causa de uma grande pressão ecológica sobre os ecossistemas costeiros insulares globais. Com o presente trabalho pretende-se rever a situação atual e os futuros cenários num arquipélago oceânico paradigmático (Ilhas Canárias, NE do Oceano Atlântico), como um caso de estudo da pegada humana nas comunidades costeiras marinhas. 0 papel dos humanos é fundamental, dado que afetam diretamente os padrões de ocupação costeira, a poluição, as espécies invasoras e/ou a pesca. Aqui sintetizamos a informação que descreve a situação atual dos ecossistemas costeiros das Ilhas Canárias, indicando as principais fontes de conflito ambiental e seus impactos. Adicionalmente, analisou-se 0 estado dos habitats mais relevantes ou ameaçados e os grupos taxonómicos como atores dos principais distúrbios nos ecossistemas costeiros do arquipélago. Propoem-se futuros cenários gerais sobre as mudanças esperadas e as interações previstas que podem. Alsotransformar os ambientes costeiros das ilhas, no intuito de indicar áreas suscetíveis de melhorias para a conservação desses ecossistemas. São necessárias ações costeiras integrativas urgentes para futuros cenários sustentáveis em oposicao a tendências deletérias, tais como tropicalização, colapso da pesca e extensa degradação costeira devido à urbanização e construção de infraestruturas.

Palavras-chave: Desenvolvimento costeiro, pesca excessiva, superpopulação, perturbação induzida pelo homem, espécies introduzidas, ilhas, arquipélağo oceânico.

1 Ecology Area, Dept. of Physical, Chemical and Natural Systems, Pablo de Olavide University, Seville, Spain.

@ Corresponding author: jddelgar@upo.es

2 Grupo en Biodiversidad y Conservación, IU-ECOAQUA, Universidad de Las Palmas de Gran Canaria, Las Palmas, 35017, Canary Islands, Spain. Email: rodrigo.riera@ulpgc.es 


\section{INTRODUCTION}

Oceanic islands are inherently fragmented environments that shelter relatively species-poor but endemism-rich biotas (Whitakker and Fernández-Palacios 2007). Species richness in oceanic islands, particularly in the tropics and subtropics, is very high in relation to its small surface area. Thus, many of them are threatened biodiversity hotspots and their contribution to global biodiversity is of paramount relevance (Myers et al., 2000, Kueffer and Kinney 2017). Climatic and oceanographic variables, mainly currents and prevailing winds, along with distance to mainland (remoteness), location regarding frequented trade routes, which is a today's proxy for effective isolation (Helmus et al., 2014, Delgado et al., 2017), and island attributes such as island origin and type (Nunn et al., 2016), topography, area and elevation (Brown and Lomolimo 1998; Whitakker and Fernández-Palacios 2007) are main determinants for the colonization of islands by species from the adjacent continents or other islands. The interaction of these features with geographical and anthropogenic factors also confers susceptibility for alien species invasions and human occupation (Russell et al., 2017).

The major immediate environmental threat to island biodiversity is the presence of humans and their associated impacts (Kier et al., 2009). Oceanic islands are usually considered more fragile than mainland areas due to combined effects of stochastic climatic events and anthropogenic disturbances that have driven extinction processes since the arrival of humans (Simberloff 1995; Graham et al., 2017). The role of human activities and related shifts in disturbance regimes on island ecosystems are often studied from a short-term perspective ( $<50$ years) (e.g. Helmus et al., 2014). However, palaecological studies on islands worldwide have shown that human impacts are not new; in most cases, the effects of human settlement are noticeable even at early stages and for long periods (Connor et al., 2012; Braje et al., 2017).

Coastal deterioration on islands has experienced severe increases during the last five decades, through peaks in touristic, constructive and extractive industries (Brooks et al., 2002; Arenas 2010; Halpern et al., 2015; Semeoshenkova and Newton 2015). This has led to a necessity of new or enhanced Marine Protected Areas (MPA) as a mean of protecting habitats and species, and of recovering biotic resources such as fisheries (Roberts et al., 2002; Edgar et al., 2014). This growing concern has led to a reinforcement of legality to detect weak points in environmental protection. In this sense, progress has been made with an overall decrease in infractions associated with several types of impacts on the marine ecosystem (Figure 1). However, this does not guarantee the absence of multidimensional and diffuse coastal impacts that escape strict legal control.

Anthropogenic disturbances, especially on oceanic islands, include irreversible abiotic and biotic alterations, such as changes in community composition, species loss (and/or gain, as invasive taxa are concerned), and biodiversity disturbances of global resonance. Often intertwined and synergic, most of these disturbance factors are commonly treated with independence from one another, and concrete impacts in different areas are reported as scattered items both in the specialized literature and from the legal and management points of view.

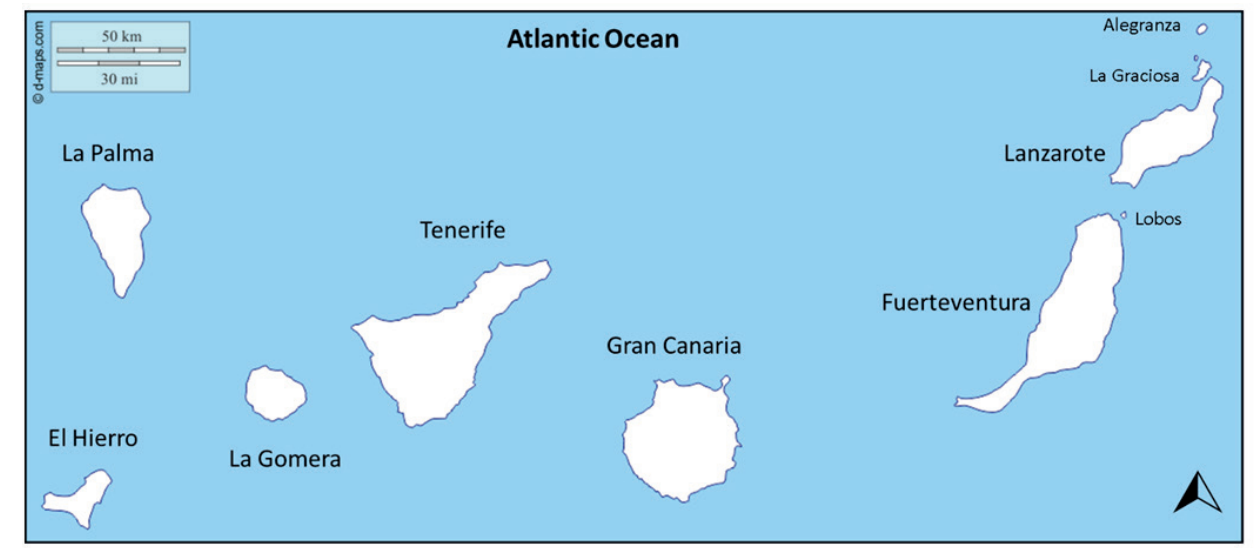

Figure 1. Map of the Canary Islands. 
Here we review the status of conservation and anthropogenic disturbances of insular coastal ecosystems, taking an oceanic archipelago, the Canary Islands (E Atlantic), as reference case. An approach to this archipelago's concrete conservation issues seems opportune because it is a well-known oceanic territory located in a secularly disturbed region of great geostrategic, economic and ecological relevance. We aimed to characterize the human footprint on these islands, providing a synthetic frame of the main causes of ecosystem degradation at the archipelago scale. We concentrated in deterioration of the biotic values of coastal assemblages, i.e. those disturbances and deleterious forces affecting mostly habitats and species, rather than focusing in general eco-health issues of the marine realm.

We approached this multifaceted problem as follows:

1. We describe the current situation, reviewing the state of habitats and relevant taxonomic groups as descriptors of the coastal marine ecosystems.

2. We outline scenarios regarding expected changes, foreseeable interactions and synergies between different sources of disturbance, which could concur to transform the coastal island environments. This would aid to identify susceptible areas to introduce strategies leading to improved sustainability.

\section{THE CURRENT SITUATION}

The key threats to the coastal ecosystems in oceanic archipelagos are those globally affecting marine flora and fauna, including climate change, non-indigenous species, and human-induced disturbances, such as overfishing and coastal development (Riera et al., 2014). There is an unprecedented rate and scale of development on oceanic islands. Such threats are accentuated in oceanic archipelagos due to massive growth of coastal settlements in the last decades, together with the presence of narrow island platforms where most of the coastal resources are confined.

\subsection{Human-induced perturbations}

A great variety of anthropogenic perturbations is currently occurring all over the planet, mostly due to the concentration of the population on coastal settlements and its subsequent pressure on the surrounding environments. Human activities present considerable threats to coastal ecosystems and resources in the following areas: (i) structure and function of natural ecosystems;

(ii) shifts in natural resources, especially commercial fisheries;

(iii) extensive transformation of coastal natural landscapes.

\subsubsection{Large scale and recreational overfishing}

Overfishing is a major anthropogenic perturbation in coastal ecosystems. Coastal resources have been overexploited throughout the last decades in many oceanic islands (e.g. Falcón et al., 1996; Tuya et al., 2004) and currently, this situation is worsening because of the growing importance of shore recreational fishing, and other activities such as uncontrolled shellfishing or indiscriminate harvesting, as well as to a lesser extent illegal underwater fishing (Castro and Hernández-García 2012, Corral et al., 2017). Canarian fishery catcheries have experienced a sharp decrease in the last four decades, from 2.2 $\mathrm{kg}$ trap $^{-1}$ day $^{-1}$ in the 1970's to 0.15-0.19 kg trap ${ }^{-1}$ day $^{-1}$ (Castro and Hernández-García 2012; García-Mederos et al., 2015). The development of an efficient management plan is a daunting task (e.g. Martínez-Saavedra 2011). Meanwhile, other factors need to be taken into account, e.g. oversizing of professional fleet and recreational fishing through the last decades (Zeller et al., 2008; Sistiaga 2011). Other "biological" factors contribute to this situation, such as the high variety of commercial fish, approximately 100 species, and the necessity to update the minimum size of captures (García-Mederos et al., 2015).

An important aspect is the increasing number of recreational anglers in the last decades. Current studies have shown that recreational fishing is responsible of $>50 \%$ of the total catches landed (Jimenez-Alvarado 2010). This trend is more accentuated in islands with scarce presence of professional fishermen, where over $60 \%$ percentages of catches comes from recreational fishing. During the last decade, the impact of recreational fishing in reducing fish stocks and invertebrates has increased substantially (Martínez-Saavedra 2011).

\subsubsection{Impacts from coastal development and infrastructures}

\subsubsection{Littoral development}

The coastal perimeter of the Canary Islands is dominated by rocky cliff shores with interspersed beaches (mainly pebble and to a lesser degree sand beaches) (Table 1). This configuration creates limited space for coastal works, and hence lesser chance to correct biotic impacts from these constructions by selecting alternative suitable locations. The coastal development includes building for residential and tourist purposes; it can be associated with installation of land transport infrastructure for access to the 
anthropogenic disturbances AND CONSERVATION OF COASTAL ENVIRONMENTS In AN OCEANIC ARCHIPELAGO

Table 1. Morphological characterization of the coastal perimeter of the Canary islands (length, in km). Data source: Instituto Canario de Estadística (ISTAC), Gobierno de Canarias.

\begin{tabular}{|c|c|c|c|c|c|c|c|c|}
\hline Coast configuration & $\begin{array}{c}\text { Canary } \\
\text { archipelago }\end{array}$ & Lanzarote & Fuerteventura & $\begin{array}{c}\text { Gran } \\
\text { Canaria }\end{array}$ & Tenerife & $\begin{array}{c}\text { La } \\
\text { Gomera }\end{array}$ & $\begin{array}{c}\text { La } \\
\text { Palma }\end{array}$ & $\begin{array}{c}\text { El } \\
\text { Hierro }\end{array}$ \\
\hline High cliffs & 720.04 & 110.59 & 99.68 & 104.49 & 137.80 & 99.43 & 102.00 & 66.05 \\
\hline Low cliffs (up to $20 \mathrm{~m}$ height) & 319.36 & 47.79 & 64.23 & 33.77 & 119.68 & 0.50 & 25.69 & 27.70 \\
\hline Low coast & 170.22 & 2.20 & 82.18 & 17.38 & 47.96 & 1.50 & 11.90 & 7.10 \\
\hline Pebble beach & 65.59 & 6.64 & 3.10 & 24.26 & 29.64 & 0.05 & 1.90 & 0.00 \\
\hline Pebble and sand beach & 93.03 & 16.94 & 22.29 & 13.37 & 12.40 & 14.62 & 8.11 & 5.30 \\
\hline Fine and coarse sand beach & 106.77 & 9.64 & 51.69 & 18.94 & 25.10 & 0.30 & 1.10 & 0.00 \\
\hline Artificial coastal works (ports) & 78.88 & 19.46 & 2.74 & 24.43 & 25.60 & 1.25 & 5.05 & 0.35 \\
\hline Total length (km) & 1553.89 & 213.26 & 325.91 & 236.64 & 398.18 & 117.65 & 155.75 & 106.50 \\
\hline
\end{tabular}

sea (roads and promenades) and marine (pontoons, marinas, and larger ports with eminently touristic use but also with commercial or industrial purposes).

The economy of this archipelago, like that of other oceanic islands, is strongly dependent on sea transport (Tovar et al., 2015). However, despite the increase in the extension and number of port infrastructures there has not been an increase in maritime traffic in the Canary Islands. Several of these large projects have indeed experienced abandonment without succeeding in stimulate local economies of that area. Some new port works have been approved with significant reductions of their original spatial and use scope, although they continue to cause significant alterations in the local coastal marine ecosystems.

Extensive projects have been developed, i.e. waterfront settlements, ports, marinas and piers, whereas in most cases lacking a sound environmental perspective, leading to severe impacts. For some projects, at least, mitigating measures have been taken, including: a) prohibition of anchoring vessels in the area of coastal influence near the port to avoid disturbances to the remaining Cymodocea beds; b) permanent sand transfer from $\mathrm{N}$ to $\mathrm{S}$ to reduce the impact of sediment loss south of port infrastructure, among others. Compensatory measures have also been addressed, mainly aimed at qualifying protected areas and restoring habitat (i.e. planting Cymodocea seagrass to rehabilitate seagrass meadows, and habitat restoration of nearby terrestrial areas).

Coastal development has significantly transformed shallow and productive coastal ecosystems into land for recreational and industrial purposes, introducing a variety of anthropogenic stressors to the coastal environment in many oceanic archipelagos. The steadily growing trend human population along and near the coast has been accompanied by new infrastructures occupying the coastal area, including the intertidal and supratidal environments (Bulleri and Chapman, 2010). Moreover, extensive coastal works have had both direct and indirect environmental effects on the ecosystems (Relini et al., 2002; Sheehy and Vik, 2010). For example, dredge and fill procedures for construction of ports and marinas not only cause short-term problems of sedimentation and turbidity, but also postponed impacts due to re-suspension of fine sediments (Erftemeijer et al., 2012).

Coastal Canarian ecosystems are heavily impacted by overpopulation (with an average of $254 \mathrm{ind} . / \mathrm{km}^{2}$, and ca 500 ind./ $\mathrm{km}^{2}$ on the islands of Tenerife and Gran Canaria; see Riera and Delgado 2019), an upward trend that still does not stop. To the pressure of the resident population must be added the "floating" or tourist population, which exceeded 6000 tourists per kilometer of coastline between 2005 and 2013 (MAGRAMA 2014; Riera and Delgado 2019). Almost 10\% of the Canary Islands' coastal perimeter is heavily transformed by the construction of breakwaters, groins, dykes and other rigid linear structures, as well as artificial beaches (ca. $80 \mathrm{~km}$ of diffrent structures along the shoreline), especially on the coasts of the southern slope of the capital islands Tenerife and Gran Canaria the use of artificial beaches (Riera et al., 2014).

As remarked by Nunn et al., (1999), smaller oceanic islands (the vast majority of them) are differentially vulnerable to coastal human impacts due to their greater amount of coastline compared to island area. It has also been argued that the distinctive nature of small islands (driven mostly by size and isolation) could determine levels of anthropogenic development 
in their ecologically limited environments (Fernandes and Pinho 2017, Delgado et al., 2017). In this sense, an influential feature conferring some passive protection from development would be the ruggedness and relief, which would be a chief constraint to urban sprawl on smaller islands with smaller availability of buildable areas (Nunn et al., 1999).

The fragmentation and individualization of coastal infrastructural projects may derive in a lack of anticipation of cumulative effects, of especial concern for small and isolated islands, exemplified by some archipelagos in the Indo-Pacific (Bass and Dalal-Clayton 1995). Solutions to such conflicts for small islands include multifunctional artificial reefs, as in Azores in the Atlantic (Ng et al., 2013), and consideration of intrinsic protective qualities integrated with sound management of native coastal ecosystems (Gracia et al., 2017).

\subsubsection{Pipelines, desalination and aquaculture}

Some activities on the coast cause a localized impact that, when repeated and accumulated along the coastal perimeter of the islands, causes synergistic and cumulative effects on a wider scale. Here we include buffer zones of pipelines, desalination plants, and aquaculture offshore cages. The environmental affection of these perturbations is limited to the adjacent area (10s to 100s meters). The addition of POM (particulate organic matter) and brine from sewage and desalination plant effluents, respectively, only affect the communities located on the proximity of the outfall (Riera et al., 2011b, 2012). This pattern is also observed on the surroundings of power station outfalls (Riera et al., 2011a), because of the presence of coastal currents through the whole water column and the rapid temperature dissipation as a consequence of temperature differences between the outfall and the receiving coastal water mass.

Offshore cages also originate a "footprint" of environmental perturbations limited to the aquaculture lease (Riera et al., 2013). However, their development has so far limited to certain archipelagos such as Canary Islands, Madeira or Hawaii, with suitable conditions for culturing temperate-water species (e.g. Kam et al., 2003). The most noticeable effects of this activity are concomitant factors, i.e. fish aggregates that are attracted by the excess organic input from uneaten pellets and fish droppings (Boyra et al., 2004). One of the main issues about fish aggregates is their concentration in a limited area, on the surroundings of cages that make them vulnerable to fishermen. Fish aggregates are characterized to be diverse and formed by several species that dominate overwhelmingly these assemblages (Riera et al., 2014). The increase of taxonomic and ecologic diversity of fish aggregates also occurs in functional terms (Riera et al., 2017), with a functionally more diverse fish community compared to sites far from cages.

\subsection{Coastal ecological imbalance}

The high degree of restriction in biotic resources, generating increased vulnerability to human exploitation, and in part as a result of this, of coupling between the marine and terrestrial biotic environments in small oceanic islands conditions the nutrient fluxes between both compartments and thus indirectly the biodiversity present in both environments (Hunt 2007). Furthermore, immigration rates to the more isolated islands like Fiji, Samoa, Easter Island and Galápagos are commonly lower than for most continental grounds or even continental platform islands, and hence losses of biotic elements from islands are more difficult to replace (Whittaker and Fernández-Palacios 2007).

In addition, smaller oceanic islands have very limited capacity to compensate for both natural and anthropogenic impacts, as well as constrained capacity to regulate its local climate. Hence, for smaller islands, mesoclimate would be strongly governed by regional-scale climate, and ecosystems would suffer from overspecialization in ecologically impacting activities such as tourism (see Wong et al., 2005, for the so-called Small Island Developing States). Coastal ecological imbalances may thus derive in a great deal from an interaction between these intrinsic vulnerabilities of oceanic islands.

Current imbalance of coastal ecosystems is perceived in several ways in oceanic archipelagos like the Canary Islands. There are consistent differences among islands within the same archipelago in human population size and density, and hence in the number and intensity of human-induced environmental disturbances. Overpopulated islands are currently suffering coastal ecological imbalance because of degradation of environmental processes, both direct and indirectly linked to human activities. Most human direct and indirect impacts occur within the first $50 \mathrm{~m}$ depth, where about half of the described species can be found (Martín 2010). These processes may be summarized in two categories: (i) outbreak of opportunistic and fast-growing species; and (ii) meteorological stochastic events.

\subsubsection{Outbreaks or die-offs of opportunistic and fast-growing species}

The proliferation of the sea urchin $D$. africanum has been responsible for an impoverishment of coastal rocky substrates in the Canarian archipelago, with the exception of El Hierro 
Table 2. Casuistic scheme of coastal management and conservation problems on oceanic islands worldwide. The list does not pretend to be exhaustive, but to review the most prevalent causes of environmental degradation in insular coastal ecosystems, with proposals for improvement from the local to the global scale.

\begin{tabular}{|c|c|c|}
\hline Example problems & Solutions/proposals of management, protection and mitigation & Site/Reference \\
\hline $\begin{array}{l}\text { - } \quad \text { Coastal degradation (seagrass beds), } \\
\text { - } \quad \text { Resort construction at the shoreline } \\
\text { - } \quad \text { Porbours and marinas control } \\
\text { - } \quad \text { Tourism impact } \\
\text { - } \quad \text { Beach nourishment }\end{array}$ & $\begin{array}{l}\text { - Urgent review of ElA licensing and resolutions for coastal deve- } \\
\text { lopments } \\
\text { - Revising strategy for marine protection and management } \\
\text { - }\end{array}$ & $\begin{array}{l}\text { Mauritius, Indian Ocean/Daby (2003) } \\
\text { Madeira (Abrantes, 2017) } \\
\text { Canary Islands (Riera et al. 2014) }\end{array}$ \\
\hline $\begin{array}{l}\text { - } \quad \text { Local fisheries affected by climate change } \\
\text { - Illegal fishing (including spearfishing and angling) } \\
\text { - Interference of foreign fleets and loss of insular } \\
\text { fishing sovereignty }\end{array}$ & $\begin{array}{l}\text { - } \quad \text { Consider needs and claims of insular artisanal fishermen } \\
\text { communities (i.e. "include all stakeholders") } \\
\text { - International protection of local traditional fisheries } \\
\text { - Modelling approaches for temporal and spatial predictions } \\
\text { - Creation of fishing reserves (Marine Protected Areas) and marine } \\
\text { sanctuaries (no-take) }\end{array}$ & $\begin{array}{l}\text { Indonesia (Sumatra, Sulawesi -Sper- } \\
\text { monde Islands)/Glaeser and Glaser } \\
\text { (2010) } \\
\text { Guadeloupe (Guyader et al. 2013) }\end{array}$ \\
\hline $\begin{array}{l}\text { - } \quad \text { Overexploitation, coastal fisheries depletion } \\
\text { - } \quad \text { Illegal fishing (including spearfishing and angling) } \\
\text { face of marine reserves acting as reservoirs in the } \\
\text { faral/human catastrophes }\end{array}$ & 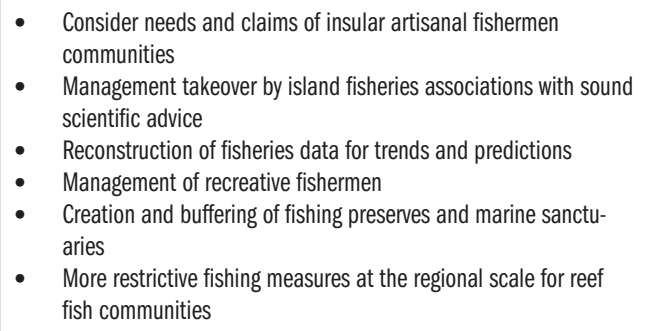 & $\begin{array}{l}\text { El Hierro and Tenerife, Canary Islands/ } \\
\text { Manrique de Lara and Corral (2017); } \\
\text { Castro et al (2019) } \\
\text { Guadeloupe (Frotté et al. 2009) } \\
\text { Galápagos (Eastern Island (Zylich et } \\
\text { al 2014) }\end{array}$ \\
\hline $\begin{array}{l}\text { - Biodiversity loss, pollution, waste management and } \\
\text { urban and industrial sewage in islands with reefs, } \\
\text { lagoons and narrow coastal areas. } \\
\text { - Growing population/tourism concentration along } \\
\text { coastal strips. } \\
\text { - Lack of trained personnel for conservation policy } \\
\text { inforcement. } \\
\text { - Monitoring difficulties due to natural isolation and } \\
\text { insularity. } \\
\text { - High economic cost of measures in impoverished } \\
\text { island nations } \\
\text { - Partial abandonment/substituion of traditional } \\
\text { activities by less sustainable ones (forced by external } \\
\text { market pressures) }\end{array}$ & $\begin{array}{l}\text { - Coral reef protection and restoration } \\
\text { - } \quad \text { Education/formation } \\
\text { - } \quad \text { Mixing traditional and modern practices [enhance traditional } \\
\text { cultural practices of exploitation, including tourism] } \\
\text { - } \quad \text { Preserve societal nets traditional to certain smaller island } \\
\text { communities from external market interference } \\
\text { - } \quad \text { Reinforcement of environmental laws, particularly in edification } \\
\text { and EIA [and public information process] } \\
\text { - Long term planning of activities with environmental incidence } \\
\text { (including tourism) } \\
\text { - Ecological coastal zonation for allowing ample spawning and } \\
\text { - } \quad \text { Pursery areas for fish [umbrela effect for biodiversity] } \\
\text { be approached sewage monitoring and waste treatment [it should } \\
\text { ber-island basis to increase efficiency] }\end{array}$ & $\begin{array}{l}\text { Pacific Ocean Islands- Oceania; } \\
\text { Indonesia; Philippines/ Thistlethwait } \\
\text { and Votaw (1992); Nunn et al. (1999); } \\
\text { Campbell (2000); Hay (2013); SPREP } \\
\text { (2016) } \\
\text { Canary Islands (Riera et al. 2014) } \\
\text { Martinica (Bocquéne \& Franco, 2005) }\end{array}$ \\
\hline $\begin{array}{l}\text { - Sea level rise; } \\
\text { - } \quad \text { Water temperature rise; } \\
\text { - Ocean acidification; } \\
\text { Other climate change consequences (especially } \\
\text { related to inherent vulnerability and low resources of } \\
\text { isolated small island states) } \\
\text { - Macro-scale oceanographic processes (El Niño or La } \\
\text { Niña, among others) }\end{array}$ & $\begin{array}{l}\text { - International compliance with climate agendas } \\
\text { - } \quad \text { Strengthen and adapt local socio-economic systems } \\
\text { - Improve and adapt coastal protections with adequate enginee- } \\
\text { ring (may require external technological support) } \\
\text { - Coral reef and mangrove protection and restoration will favor } \\
\text { habitat integrity, sediment stability, fisheries nurturing, shoreline } \\
\text { protection }\end{array}$ & $\begin{array}{l}\text { Pacific Ocean Islands (including small } \\
\text { island states); Indonesia/ Mimura } \\
\text { and Nunn (1998); Nunn et al. (1999); } \\
\text { Christie (2005); Gilman et al. (2006); } \\
\text { Campbell (2009); Ellison (2010); Hay } \\
\text { (2013) } \\
\text { Galápagos (Eddy et al. 2019) }\end{array}$ \\
\hline $\begin{array}{l}\text { - Degradation by urbanization of intertidal rocky and } \\
\text { sandy shores, halophytic vegetation and dune fields. }\end{array}$ & $\begin{array}{l}\text { - Monitoring and protection of scarcer sedimentary coasts (i.e. } \\
\text { sand dunes) } \\
\text { - Coastal moratory }\end{array}$ & $\begin{array}{l}\text { Canary Islands/ Bianchi (2004); Otto } \\
\text { et al. (2007); Fernández-Cabrera et al. } \\
\text { (2011); Delgado et al. (2017); Ferrer- } \\
\text {-Valero et al. (2017) }\end{array}$ \\
\hline $\begin{array}{l}\text { - Fisheries and shellfish over-exploitation in relation } \\
\text { to poor self-management of local fishermen guilds } \\
\text { (“cofradías"); commercialisation problems; por } \\
\text { co-management strategies; illegal fishing; artisanal } \\
\text { fishing decline }\end{array}$ & $\begin{array}{l}\text { - Adapt regulations to the needs and integrate knowledge of the } \\
\text { local fishermen's guilds; promote fishermen participation and } \\
\text { collaborative strategies }\end{array}$ & $\begin{array}{l}\text { Tenerife, Canary Islands/ Corral et al. } \\
\text { (2017) }\end{array}$ \\
\hline
\end{tabular}


Table 2. Casuistic scheme of coastal management and conservation problems on oceanic islands worldwide. The list does not pretend to be exhaustive, but to review the most prevalent causes of environmental degradation in insular coastal ecosystems, with proposals for improvement from the local to the global scale.

\begin{tabular}{|c|c|c|}
\hline Example problems & Solutions/proposals of management, protection and mitigation & Site/Reference \\
\hline $\begin{array}{ll}\text { - } & \text { Elevated population density } \\
\text { - } & \text { Tourism, beach disturbance } \\
\text { - } & \text { Agriculture (fertilizers, pesticides); eutrophication } \\
\text { - } & \text { Oversedimentation } \\
\text { - } & \text { Overfishing/aquaculture } \\
\text { - } & \text { Industrial pollution (heavy metals, hydrocarbons) } \\
\text { - } & \text { Silting and pollution of coastal lagoons and estuaries } \\
\text { - } & \text { Sewage discharges } \\
\text { - } & \text { Maritime traffic } \\
\text { - } & \text { Invasive alien species (i.e. algae) } \\
\text { - } & \text { Loss of seagrass meadows and associated biodi- } \\
& \text { versity }\end{array}$ & $\begin{array}{l}\text { - } \quad \text { Strengthen legal protection in biodiversity hotspots } \\
\text { - } \quad \text { Measures to minimize eutrophication and reduce phytoplankton } \\
\text { blooms } \\
\text { - } \quad \text { Functional monitoring in sensible sites } \\
\text { - } \\
\text { Protect sensible sites from further port and marina development; } \\
\text { strengthen Environmental Impact Assessment }\end{array}$ & $\begin{array}{l}\text { Mediterranean Sea/ European Commu- } \\
\text { nities (1999, 2000); Güreen et al. } \\
\text { (2020); Waycott et al. (2009); Myers } \\
\text { et al. (2000) }\end{array}$ \\
\hline $\begin{array}{l}\text { - Trade-off between coastal conservation and human } \\
\text { behavior at a local scale }\end{array}$ & $\begin{array}{l}\text { - Analyzing perceptual social data for improving resource mana- } \\
\text { gement }\end{array}$ & $\begin{array}{l}\text { Caribbean Sea coasts and islands, and } \\
\text { other global coastal regions/ Aswani } \\
\text { (2019) }\end{array}$ \\
\hline $\begin{array}{l}\text { Macro- and microplastic pollution in coastal waters, } \\
\text { beaches, and seafloor sediments, reaching even } \\
\text { remote oceanic islands. }\end{array}$ & $\begin{array}{l}\text { - } \quad \text { Palliative cleanups } \\
\text { - } \quad \text { Preventive actions (prohibition/banning of packaging \& other } \\
\text { non-biodegradable plastic ítems) } \\
\text { - } \quad \text { Shift to biodegradable materials } \\
\text { - } \quad \text { Education to consumers } \\
\text { - } \quad \text { ontrol spilling from both land- (rivers, submarine sewage } \\
\text { - } \quad \text { Analysis of presence in trophic chains }\end{array}$ & $\begin{array}{l}\text { Global islands and coasts, all oceans/ } \\
\text { Monteiro et al. (2018); Ling et al. } \\
\text { (2017) }\end{array}$ \\
\hline
\end{tabular}

where the fishing pressure has been lower and more strictly regulated in recent decades (Tuya et al., 2004). Several environmental factors are likely to have played a role in the demographic explosion of $D$. africanum populations in the Canaries (Clemente et al., 2009), being the overfishing of predators, e.g. hogfishes, snappers and groupers, the most important (Tuya et al., 2004). Also, other anthropogenic factors are considered to be associated with increased abundances of $D$. africanum, such as the population density and the numbers of fishing boats (Hernández et al., 2008). The outbreak of this voracious sea urchin results in commonly spreading barren grounds throughout the entire archipelago (Brito et al., 2004), reaching up to $50 \mathrm{~m}$ depth and covering approximately $75 \%$ of rocky substrates of the Canary Islands (Barquín et al., 2004). Even, small densities $\left(<5\right.$ ind. $\left.\mathrm{m}^{-2}\right)$ can remove up most of the algal cover and thus reduce significantly macroalgal diversity, resulting in impoverished bottoms dominated by encrusting algae (Sangil et al., 2012).

In comparison, in the Caribbean islands, the situation is radically different with major algal growths developed over reefs following the mass mortality throughout the 80s of the long-spined sea urchin Diadema antillarum caused by a toxic infection (Hughes et al., 1985). The current population densities are ca. $12 \%$ of those before the die-off, and still the factors are unclear though recruitment limitation seems to be a pivotal factor (Lessios, 2016). This urchin is a keystone herbivore on Caribbean coral reefs, controlling benthic algae growth by grazing on macroalgae; this species is responsible for $40 \%$ of the grazing activity that occurs on a coral reef (Mumby et al., 2006). Thus, the dieoff of this sea urchin species underpinned a shifting baseline from coral-dominated to algae-dominated communities, since macroalgae compete and harm corals (Rivers and Edmunds, 2001).

Climatic variables are primary drivers of distributions and dynamics of marine communities in coastal ecosystems (Parmesan 2006). However, global climate change is affecting the marine realm in different ways, e.g. warming waters, acidification and anoxia, and thus, several species are favored by these changes compared to other. Moreover, coastal ecosystems are subjected to multiple drivers of human-induced environmental changes. One of the consequences of these changes is the increase of opportunistic fast-growth species, better adapted to the current fluctuating conditions. These outbreaks in turn may cause changes in the structure and function of the broader ecological community, with modifications in physical-chemical properties of the ecosystem (Valiela et al., 
1997). Most of the blooms are normally formed by opportunistic algae, which are a natural component of shallow subtidal marine communities, however, humans promote the magnitude, frequency and duration of their proliferation by increasing nutrient loads in coastal waters, e.g. pipelines, run-offs, etc. (Eriksson et al., 2009).

In the Canary Islands, blooms of the blue-green algae Lyngbya majuscule, linked to declines in the abundance of the seagrass Cymodocea nodosa, have been observed in the eastern islands (Martín-García et al., 2014). In addition, two green algae (Caulerpa racemosa and $C$. prolifera) have proliferated in cover and extension in C. nodosa meadows (Tuya et al., 2014a). These algae are better adapted to eutrophic conditions, and even manipulative experiments have shown faster growth rates of Caulerpa occupying $C$. nodosa habitats (Tuya et al., 2013). In addition, the growth of Caulerpa is favored by high sedimentation and resuspension rates (Williams 2007). Other factors that are steadily increasing in importance affecting seagrass ecosystems include pollution from several industrial and aquaculture activities (Riera et al., 2013).

\subsubsection{Non indigenous species (NIS)}

Probably, a net gain of species has been shown in the last decades as consequence of the non-indigenous species reports, mostly associated to fouling (Godwin, 2003) and shipping traffic (Ware et al., 2014). However, this species increase is not relative to the species loss that is positively correlated to the human pressure on the coastal environment, e.g. Canary Islands (Riera et al., 2014).

Non-native, introduced marine organisms can act as competitors, predators and as ecological engineers in the recipient ecosystems (Wallentinus and Nyberg 2007). The threat to biodiversity posed by invasive taxa is increasing as the arrival of new species is facilitated by ocean warming and international maritime traffic (0cchipinti-Ambrogi and Savini 2003; Molnar et al., 2008). For example, the species Zoobotryon verticillatum, originally from the Mediterranean Sea, have greatly expanded its biogeographic range by the proliferation of marinas and vessel traffic in the Atlantic Ocean (Minchin 2012).

Hull fouling, ballast waters and sediments from commercial ships and recreational yachts constitute important vectors for introducing NIS to oceanic archipelagos. Oil platforms have also recently been identified as a vector of exotic tropical fish from Brazil, Guinea, or the Caribbean (Falcón et al., 2015). Sea warming is also an environmental factor creating favorable conditions for an increase in tropical and subtropical fauna and flora, partially due to latitudinal shifts or range expansions (e.g. Brito et al., 2005). However, in several cases the arrival of exotic species cannot be plainly interpreted as a human-mediated invasion, but as a spontaneous process, although human activities can introduce favoring synergies (i.e. oil platforms and ships as vectors for algae, invertebrates and fishes, fish farming cages) in an already-occurring tropicalization scenario.

Ballast water transported by globally increased ship traffic, along with other interacting factors such as nutrient imbalances, salinity, acidity and temperature changes, and coastal degradation, may be enhancing the risk of toxic microalgal outbreaks (Ruiz, 2000). Shipping traffic has other inherent consequences concerning antifouling products, especially in the last decades after the ban-use of Tributyltin (TBT) due to its toxicity and persistence. Currently, other biocides for ship hulls of any length have been tested (Sánchez Rodríguez et al., 2011); however, their toxicological effects are not well studied, especially for non-target species, e.g. gastropods and bivalves (Sánchez Rodríguez et al., 2011).

\section{FUTURE SCENARIOS}

The current environmental situation in most of oceanic archipelagos is a consequence of several factors and will be accentuated in the next decades, with an increase of coastal degradation and the number of environmental perturbations that interact and establish ecological synergies deserving further attention.

\subsection{Prospects of a gradual tropicalization of the Canary islands}

Seawater warming has profound consequences on coastal populations, community composition and ecosystem functions (IPCC 2014). For example, the tropicalization of ecosystems drives changes in herbivory, with a deforestation of temperate algal forests and seagrass beds due to the expansion of tropical herbivores (Vergés et al., 2014). In some coastal temperate areas, the increase of sea surface temperature and a rise of tropical fish abundance have coincided with a dramatic decline in macroalgal beds (Nagai et al., 2011). In the last decades, sea warming has been starting to affect the structure of coastal ecosystems in the Canaries with the appearance of species with tropical affinities, from Cape Verde, the West African coast and the Caribbean as main biogeographic origins (Riera et al., 2014). 
The growing prevalence of tropicalized climate, i.e. sea warming temperature (Parrilla et al., 1994; Santos et al., 2012), including warming of the Canary Current upwelling, (Arístegui et al., 2009), and other influential phenomena such as increases in algal fertilization from Saharo-Sahelian dust plumes (Alonso-Pérez et al., 2007), may establish favorable conditions for phytoplankton blooming events. Many new species are being described with the mentioned potential for ecological change of coastal ecosystems and with repercussions in other environments, as occurred to the recently discovered dinoflagellates Gambierdiscus excentricus (Fraga et al., 2011) and G. silvae (Fraga and Rodríguez 2014).

An obvious tropicalization of littoral fish fauna has been experienced in the Canarian archipelago over the last two decades (Falcón et al., 2015). Examples of this process are the ocean triggerfish (Canthidermis sufflamen) and goldspot goby (Gnatholepis thomsoni) (Brito et al., 2005). In contrast, there are evidences showing the regression of temperate species such as the seastar Marthasterias glacialis (Authors pers. obs.) and fucoid algae, i.e. Fucus guiryi (Riera et al., 2015). Even a decreasing trend in coral populations has been observed in the black coral Antipathella wollastoni at shallow seabeds throughout the Archipelago, with most of the remaining populations at higher depths (> $45 \mathrm{~m}$ ) forming dense aggregations (Martín-García 2013).

\subsection{Fisheries collapse}

Catcheries have shown clear symptoms of overfishing throughout the last decades (García-Mederos et al., 2015). The steadily increasing pressure from recreational fishermen is a factor of utmost importance to take into account for future works on fisheries effort and landings. Professional fishers are currently limited to certain coastal settlements, focused on a very limited array of target species (Balguerías 2001), and represent a minor fraction of the landings. The collapse of several commercial species is eminent in the near future since the fishing pressure is not decreasing and stocks are on the brick of sustainability for most of the species, with special emphasis on groupers and snappers (García-Mederos et al., 2015).

Riera et al., (2016) have shown a dramatic decrease of two commercial limpet sizes (Patella candei crenata and Patella aspera), indicative of overharvesting, mainly conducted by recreational harvesters. The limpet size is considered a surrogate of the state of the conservation of their stocks, and thus, the low viability of limpet populations is evident in the Canarian archipelago.

\subsection{New pollution concerns}

Increasing coastal human presence and seaside recreation at a global scale is related to pollution through microplastics, metals, ultraviolet (UV) filters and other pollutants that bioaccumulate in marine organisms with potential risks for both humans and the marine environments (e.g. coral bleaching by viral infections, among other effects) (Danovaro et al., 2008; Sánchez Rodríguez et al., 2015). The rise of plastic in human industrial chains means a new quanti- and qualitative leap in our way of damaging marine ecosystems. It represents the epitome of an unsustainable use of the oceans as a garbage dump.

In this sense, recent studies have alerted of pervasive presence of microplastics in sandy substrata, although biotic effects are still poorly known (Baztan et al., 2014). Little is known of the longterm effects of plastics and microplastics at different levels of the marine food chain. The type of compounds derived from the degradation of plastics, associated with the type of damage they can cause in different types of organisms, including humans, is scarcely known. Methods to characterize and identify composition and origin of plastic debris are being developed (La Daana et al., 2017, Serranti et al., 2018). A low prevalence of microplastics has been found in fish caught in coastal waters of the South Pacific. This has been explained by low human presence in that region and by the great dynamism of the currents that move coastal water outwards through upwelling and (Ory et al., 2018). However, contamination by plastics in coastal waters and beaches of the Atlantic islands (e.g. Makaronesia and the Caribbean) is already an important problem (Monteiro et al., 2018). The information again seems to be more focused on sandy beach environments because these are the most accessible for human use. Other coastal configurations, dominant in certain volcanic islands, are poorly studied. In a study from beaches in the Canary Islands, the characteristic debris types collected pointed to open-sea sources rather than land-based or local ones (Herrera et al., 2018). However, the relative importance of diffuse sources compared with point sources of plastic discharge to the sea is not well known, although certainly a very high percentage would come from river discharge and land-based industries and cities (Herrera et al., 2018).

The long-term global effects of microplastics and other pollutants on biodiversity and the integrity of marine trophic networks are difficult to predict. Certain questions remain thus open. How do microplastics interact with other types of contaminants? What are its short and long-term effects on food webs and finally on human 
health? How can pollution by microplastics affect fisheries? Above all, what mechanisms and strategies are we applying to tackle this global problem?

\subsection{Extensive coastal degradation}

Coastal development affects over $80 \%$ of the coastline in many European regions, and it is responsible for much of the observed habitat degradation and loss (Airoldi and Beck, 2007). Coastal occupation underpins profound changes in ecosystem functioning, which are not limited to short-term effects since drivers or consequences that may be developed because of these changes (Biggs et al., 2009). Ecological consequences of coastal transformation have not been fully appreciated or brought into a proper conservation context, due to a preponderance of management implementations and infrastructure schemes applied in response to emergence situations, or in exclusive dedication to human welfare, leisure or economic criteria (Semeoshenkova and Newton 2015).

Degradation of coastal and marine ecosystems through urbanization has been increasing on the islands during the last half century, long before the first marine reserves were firstly conceived and proposed in the 1980s (e.g. Bacallado et al., 1989). Coastal development, urbanization, intensive agriculture and mass tourism pressure have contributed to an irreversible transformation of several coastal habitats from oceanic archipelagos (0tto et al., 2007; Bertocci et al., 2016). Such activities interact (and compete) with other activities in the primary sector such as both recreational and traditional fisheries, as well as aquaculture industry (Chuenpagdee et al., 2013).

On the other hand, the construction of "mega" infrastructures such as ports affects extensive coastal areas (Sundblad and Bergström, 2014). The development plans of several islands include the construction of future harbor infrastructures, as well as the creation of artificial beaches with subsequent beach nourishment actions. The environmental affections of these infrastructures are not exclusively limited to the coastal area but to the surrounding environment, with changes in hydrodynamics, physico-chemical and biological factors, among others (Martins et al., 2016).

Besides, impacts of land logistic facilities and transport infrastructure associated to harbors and marinas would add additional impacts (i.e. changes in water runoff affecting sedimentation, and pollution sources) at different levels upon mesolittoral and sublittoral habitats. Moreover, such land changes add and accumulate with landscape transformation (urbanization, agriculture; see 0tto et al., 2007); this implies indirect effects on the marine environments. The stakeholders have traditionally shown reticence against the creation of marine reserves and protection of relevant marine environments around the islands, although already even some fishermen associations have acknowledged the benefits on the long term, for example in the MPA Mar de las Calmas (El Hierro) (Jentoft et al., 2012).

Finally, the worldwide approach to the conservation schemes of species is becoming growingly reactive and species-focused, rather than adaptive and habitat- or ecosystem-focused. This approach seems to favor species over habitats as protection subjects, and responds to a generalized prioritization of the development of coastal infrastructure and logistic schemes over efficient habitat conservation. In terrestrial coastal ecosystems, it has been suggested that protection of relatively small areas does not avoid massive loss of natural areas (0tto et al., 2007). Far from slowing down, the last decades have seen further irreversible coastal degradation and destruction of natural areas due to coastal development. In the Canary Islands, this has occurred simultaneously to reductions in protection status of concrete figures for both species and habitats, and to the inclusion of "selected" taxa in protection lists within the category "Species of Interest for the Canary Islands", rather than enhancing protection of certain idiosyncratic and singular environments whose preservation would render improved conservation status of species in the future, if basic principles of biological conservation were applied.

Nevertheless, in the last decade, conservation efforts have shown some positive results, with the recovery of populations of endangered species such as, cetaceans, turtles and seals (Bejder et al., 2016, Piacenza et al., 2016, Magera et al., 2013), as well as signs of reverse of the decline of exploited species, e.g. fish commercial stocks in several areas where they were depleted by industrial fleet (e.g. Froese et al., 2018). Recently, Duarte et al (2020) outlined the importance of fulfilling the Sustainable Development Goal 14 of the United Nations aims to "conserve and sustainably use the oceans, seas and marine resources for sustainable development". This goal is achieved by rebuilding not only species on decline but ecosystems that have disappear or in at risk of destruction from human-driven perturbations. In the last decade, an increase number of restoration projects and initiative have been developed worldwide on declining coastal ecosystems, namely mangroves, seagrass meadows, kelp forests and coral reefs. 


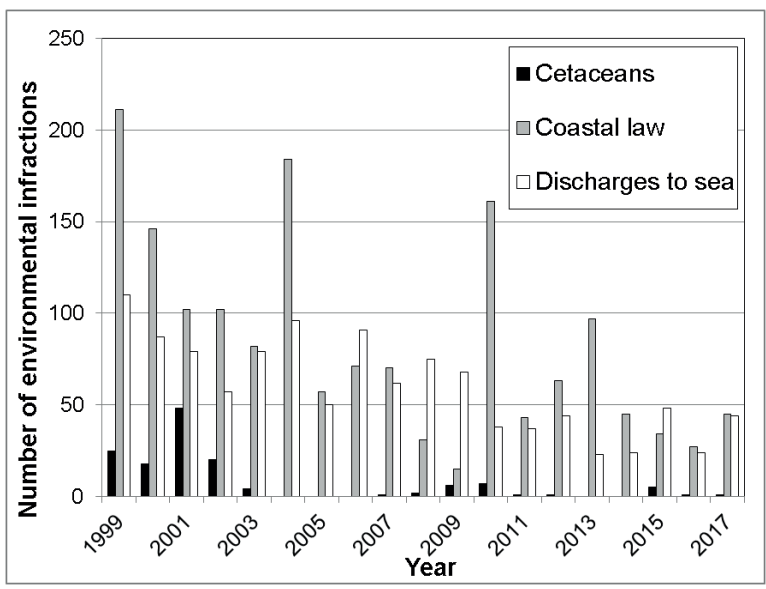

Figure 2. Evolution of the absolute number of environmental infractions related to marine ecosystems in the Canary archipelago. The data relating to infractions on cetacean conservation, illegal discharges to the sea and infractions of the Coast law are shown. Data source: ISTAC (Instituto Canario de Estadística; Estadística de Vigilancia Ambiental / Resultados principales. Islas de Canarias. 1999-2017).

\section{CONCLUSIONS}

The increase in resource exploitation, extractive activities and use and abuse of the coastline entail onerous environmental costs in the Canarian archipelago and other islands worldwide. Society-environment positive synergies should be pursued to ameliorate exacerbated pressure on island coastal resources. Involvement of public administrations, citizenship environmental education to minimize diffuse pollution, updated and effective fisheries management supported by a strict surveillance and gremial participation, monitoring of ballast waters and hull fouling of vessels and oil platforms, and legal control of development within integrated coastal zone management (ICZM), are all urgently needed measures for sustainable future scenarios in most oceanic archipelagos.

\section{ACKNOWLEDGEMENTS}

To Dr. Fernando Tuya (University of Las Palmas de Gran Canaria) for interchange of ideas and constructive discussion through the preparation of this manuscript.

\section{REFERENCES}

Abrantes, A.C. (2017) - New ports of the New World: Angra, Funchal, Port Royal and Bridgetown. International Journal of Maritime History, 29:1

Airoldi, L.; Beck, M.W. (2007) - Loss, status and trends for coastal marine habitats of Europe. Oceanography and Marine Biology - An Annual Review, 45: 345-405.

Alonso-Pérez, S; Cuevas, E; Querol, X; Viana, M; Guerra, J.C. (2007) - Impact of the Saharan dust outbreaks on the ambient levels of total suspended particles (TSP) in the marine boundary layer (MBL) of the Subtropical Eastern North Atlantic Ocean. Atmospheric Environment, 41: 9468-9480.

Arenas, P. (2010) - Gestión del litoral y política pública en España: Un diagnóstico. pp. 353-380. In: Barragán, J.M., (ed.), Manejo costero integrado y política pública en Iberoamérica: Un diagnóstico. Necesidad de Cambio. Red IBERMAR (CYTED), Cádiz.

Arístegui, J.; Barton, E.D.; Álvarez-Salgado, X.A.; Santos, A.M.P.; Figueiras, F.G.; Kifani, S.; Hernández-León, S.; Mason, E.; Machú, E.; Demarcq, H. (2009) - Sub-regional ecosystem variability in the Canary Current upwelling. Progress in 0ceanography, 83: 33-48.

Aswani, S. (2019) - Perspectives in coastal human ecology (CHE) for marine conservation. Biological Conservation, 236:223-235.

Bacallado, J.J.; Cruz, T.; Brito, A.; Barquín, J.; Carrillo, M. (1989) Reservas marinas de Canarias. Consejería de Agricultura y Pesca. Gobierno de Canarias. Santa Cruz de Tenerife, 200 pp.

Balguerías, E. (2001) - La Pesca. Pp. 275-282, In: (Fernández-Palacios, J.M., Martín Esquivel, J.L. (eds.). Naturaleza de las Islas Canarias. Ecología y Conservación. Turquesa, Santa Cruz de Tenerife, 474 pp.

Barquín, J.; Gil-Rodríguez, M.C.; Del Arco Aguilar, M.J.; DomínguezÁlvarez, S.; González, R.; Aldanondo-Aristizábal, N.; Rodríguez, M.; CruzReyes, M.A.; Herrera-López, G.; Sancho, A.; Cruz, T.; 0`Dwyer, J.; Martín, L.; Cansado, S. (2004) - La cartografía bionómica del litoral de Tenerife: resultados preliminares. XIII Simposium Ibérico del Estudio del Bentos Marino. Libro de resúmenes, 219 pp.

Bass, S.; Dalal-Clayton, B. (1995) - Small island states and sustainable development: strategic issues and experience. Environmental Planning Issues, $8.59 \mathrm{p}$.

Baztan, J.; Carrasco, A.; Chouinard, 0.; Cleaud, M.; Gabaldon, J.E.; Huck, T.; Jaffrès, L.; Jorgensen, B.; Miguelez, A.; Paillard, C.; Vanderlinden, J-P. (2014) - Protected areas in the Atlantic facing the hazards of micro-plastic pollution: First diagnosis of three islands in the Canary Current. Marine Pollution Bulletin, 80:302-311.

Bejder, M.; Johnston, D.; Smith, J.N.; Freidlaender, A.; Bejder, L. (2016) - Embracing conservation success of recovering humpback whale populations: evaluating the case for downlisting the conservation status in Australia. Mar. Policy, 66:137-141.

Bertocci, I.; Arenas, F.; Cacabelos, E.; Martins, G.M.; Seabra, M.I.; Álvaro, N.V.; Fernandes, J.N.; Gaiao, R.; Mamede, N.; Mulas, M.; Neto, A.I. (2016) - No where safe? Exploring the influence of urbanization across mainland and insular seashores in continental Portugal and the Azorean archipelago. Marine Pollution Bulletin, 114:644-655. 
Bianchi, R.V. (2004) - Tourism restructuring and the politics of sustainability: A critical view from the European periphery (The Canary Islands). Journal of Sustainable Tourism, 12(6):495-529.

Biggs, R.; Carpenter, S.R.; Brock, W.A. (2009) - Turning back from the brink: Detecting an impending regime shift in time to avert it. Proceedings National Academy of Sciences, 106:826-831.

Bocquené, G.; Franco, A. (2005) - Pesticide contamination of the coastline of Martinique. Marine Pollution Bulletin, 51(5-7):612-619.

Boyra, A.; Sánchez-Jerez, P.; Tuya, F.; Espino, F.; Haroun, R. (2004) Attraction of wild coastal fishes to Atlantic subtropical cage fish farms, Gran Canaria. Environmental Biology of Fishes, 70:393-401.

Braje, T.; Leppard, T.; Fitzpatrick, S.; Erlandson, J. (2017) Archaeology, historical ecology and anthropogenic island ecosystems. Environmental Conservation, 44:286-297.

Brito, A.; Falcón, J.M.; Herrera, R. (2005) - Sobre la tropicalización reciente de la ictiofauna litoral de las islas Canarias y su relación con cambios ambientales y actividades antrópicas. Vieraea, 33:515-525.

Brito, A.; Hernández, J.C.; Falcón, J.; García, N.; González-Lorenzo, G.; Gil-Rodríguez, M.C.; Cruz, A.; Herrera, G.; Sancho, A.; Clemente, S.; Cubero, E.; Girard, D.; Barquín, J. (2004) - El erizo de lima (Diadema antillarum): una especie clave en los fondos litorales rocosos de Canarias. Makaronesia 6:68-86.

Brito, M.C.; Martin, D.; Núñez, J. (2005) - Polychaetes associated to a Cymodocea nodosa meadow in the Canary Islands: assemblage structure, temporal variability and vertical distribution compared to other Mediterranean seagrass meadows. Marine Biology, 146:467-481.

Brooks, T.M.; Mittermeier, R.A.; Mittermeier, C.G.; Da Fonseca, G.A.B.; Rylands, A.B.; Konstant, W.R.; Flick, P.; Pilgrim, H.; Oldfield, S.; Magin, G.; Hilton-Taylor, C. (2002) - Habitat loss and extinction in the hotspots of biodiversity. Conservation Biology, 16(4):909-923.

Brown, J.; Lomolino, M. (1998) - Biogeography (2nd edition). Sunderland, M.A., Sinauer Associates, Inc., 691 pp.

Bulleri, F.; Chapman, M.G. (2010) - The introduction of coastal infrastructure as a driver of change in marine environments. Journal of Applied Ecology, 47:26-35.

Campbell, J. (2009) - Islandness: vulnerability and resilience in 0ceania. Shima Int. J. Res. Isl. Cultures, 3(1):85-97.

Castro, J.J.; Divovich, E.; Delgado A.; Barrera-Luján, A.; Riera, R. (2019) Reconstruction of marine small-scale fisheries captures in the Canary Islands (NE Atlantic Ocean) from 1950 to 2010. Scientia Marina, 83(1):7-17.

Castro, J.J.; Hernández-García, V. (2012) - Caracterización del poder de pesca de la flota artesanal canaria, con especial referencia a la fracción con eslora superior a $12 \mathrm{~m}$, y análisis del estado de los recursos que explota. Informe Técnico. Viceconsejería de Pesca y Aguas del Gobierno de Canarias, 127 pp.
Christie, P. (2005) - Is Integrated Coastal Management Sustainable? Ocean \& Coastal Management, 48:208-232.

Chuenpagdee, R.; Pascual-Fernández, J.J.; Szeliánszky, E.; Alegret, J.L.; Fraga, J.; Jentoft, S. (2013) Marine protected areas: Re-thinking their inception. Marine Pollution, 39:234-240.

Clemente, S.; Hernández, J.C.; Brito, A. (2009) - Evidence of the topdown role of predators in structuring sublittoral rocky-reef communities in a marine protected area and nearby areas of the Canary Islands. ICES Journal of Marine Science, 66:64-71.

Connor, S.E.; van Leeuwen, J.F.N.; Rittenour, T.M.; van der Knaap, W.0.; Ammann, B.; Björck, S. (2012) - The ecological impat of oceanic island colonization - a palaeoecological perspective from the Azores. Journal of Biogeography, 39:1007-1023.

Corral, S.; Manrique de Lara, D.R. (2017). Participatory artisanal fisheries management in islands: Application to the Canary Islands (Spain). Marine Policy, 81: 45-52.

Daby, D. (2003) - Effects of seagrass bed removal for tourism purposes in a Mauritian bay. Environmental Pollution, 125:313-324.

Danovaro, R.; Bongiorni, L.; Corinaldesi, C.; Giovannelli, D.; Damiani, E.; Astolfi, P.; Greci, L.; Pusceddu, A. (2008) Sunscreens cause coral bleaching by promoting viral infections. Environmental Health Perspectives, 116:441-447.

Delgado, J.D.; Riera, R.; Rodríguez, R.A.; González-Moreno, P.L.; Fernández-Palacios, J.M. (2017) - A reappraisal of the role of humans in the biotic disturbance of islands. Environmental Conservation, 44(4): 371-380.

Duarte, C.M.; Agusti, S.; Barbier, E. et al. (2020) - Rebuilding marine life. Nature, 580:39-51.

Eddy, T.D.; Friedlander, A.M.; Salinas de León, P. (2019) - Ecosystem effects of fishing \& El Niño at the Galágos Marine Reserve. PeerJ, 7:e6878.

Edgar, G., et al. (2014) - Global conservation outcomes depend on marine protected areas with five key features. Nature, 506:216-220.

Ellison, J.C. (2010) - Vulnerability of Fiji's mangroves and associated coral reefs to climate change. A Review. Suva, Fiji, WWF South Pacific Office.

Erftemeijer, P.L.A.; Riegl, B.; Hoeksema, B.W.; Todd, P.A. (2012) Environmental impacts of dredging and other sediment disturbances on corals: A review. Marine Pollution Bulletin, 64:1737-1765.

Eriksson, B.K.; Ljunggren, K.; Sandstrom, A.; Johansson, G.; Mattila, J.; Rubach, A.; Raberg, S.; Snickars, M. (2009) - Declines in predatory fish promote bloom-forming macroalgae. Ecological Applications, 19:1975-1988.

European Communities. (1999) - State and pressures of the marine and coastal Mediterranean environment. Luxembourg: Office for 
Official Publications of the European Communities. UNEP \& European Environmental Agency. Environmental issues series № 5., 137 p.

European Communities. (2000) - DIRECTIVE 2000/60/EC of the European parliament and of the council, of 23 October 2000, establishing a framework for Community action in the field of water policy. Official Journal of the European Communities, G.U.C.E. 22/12/2000, L 327.

Falcón, J.M.; Bortone, S.A.; Brito, A.; Bundrick, C.M. (1996) - Structure and relationships within and between the littoral, rock-substrate fish communities off four islands in the Canarian Archipelago. Marine Biology, 125:215-231.

Falcón, J.M.; Herrera, R.; Ayza, 0.; Brito, A. (2015) - New species of tropical littoral fish found in Canarian waters. Oil platforms as a central introduction vector. Revista de la Academia Canaria de Ciencias, 27:67-82.

Fernandes, R.; Pinho, P. (2017) - The distinctive nature of spatial development on small islands. Progress in Planning, 112:1-18.

Fernández-Cabrera, E.; Pérez-Chacón Espino, E.; Cruz Avero, N.; Hernández-Cordero, A.; Hernández-Calvento, L. (2011) - Consecuencias ambientales del crecimiento urbano-turístico en el sistema de dunas de Corralejo (Fuerteventura-Islas Canarias). In V. Gozálvez-Pérez \& J. A. Marco-Molina (Eds.), Urbanismo expansivo de la utopía a la realidad (pp. 241-252). Asociación de Geógrafos Españoles: Colegio de Geógrafos de España y Universidad de Alicante, Alicante.

Ferrer-Valero, N.; Hernández-Calvento, L.; Hernández Cordero, A.I. (2017) - Human impacts quantification on the coastal landforms of Gran Canaria Island (Canary Islands). Geomorphology 286:58-67.

Fraga, S.; Rodríguez, F. (2014) - Genus Gambierdiscus in the Canary Islands (NE Atlantic Ocean) with description of Gambierdiscus silvae sp. nov., a new potentially toxic epiphytic benthic dinoflagellate. Protist, 165:839-853.

Fraga, S.; Rodríguez, F.; Caillaud, A.; Diogène, J.; Raho, N.; Zapata, M. (2011) - Gambierdiscus excentricus sp. nov. (Dinophyceae), a benthic toxic dinoflagellate from the Canary Islands (NE Atlantic Ocean). Harmful Algae, 11:10-22.

Froese, R.; Winker, H.; Coro, G.; Demirel, N; Tsikliras, A.C.; Dimarchopoulou, D.; Scarcella, G.; Quaash, M.; Matz-Lück, N. (2018) - Status and rebuilding of European fisheries. Marine Policy, 93:159170.

Frotté, L.; Harper, S.; Veitch, L.; Booth, S.; Zeller, D. (2009) Reconstruction of marine fisheries catches for Guadeloupe from 19502007. Fisheries Centre Research Report, University of British Columbia.

García-Mederos, A.; Tuset, V.M. (2014) - First record of African brown snapper Lutjanus dentatus in the Canary Islands (north-eastern Atlantic Ocean). Marine Biodiversity Records, 7:e65. doi:10.1017/ S1755267214000682.
García-Mederos, A.; Tuya, F.; Tuset, V.M. (2015) - The structure of a nearshore fish assemblage at an oceanic island: insight from smallscale fisheries through bottom traps at Gran Canary Island (Canary Islands, Eastern Atlantic). Aquatic Living Resources, 28:1-10.

Gilman, E.L.; Ellison, J.; Jungblut, V.; Lavieren, H.V.; Wilson, L.; Areki, F.; Brighouse, G.; Bungitak, J.; Dus, E.; Henry, M.; Kilman, M.; Matthews, E.; Sauni Jr. I.; Teariki-Ruatu, N.; Tukia, S.; Yuknavage, K. (2006) Adapting to Pacific Island mangrove responses to sea level rise and climate change. Climate Change 32:161-176.

Glaeser, B.; Glaser, M. (2010) - Global change and coastal threats: The Indonesian case. Human Ecology Review, 17(2):135-147.

Godwin, L.S. (2003) - Hull fouling of maritime vessels as a pathway for marine species invasions to the Hawaiian Islands. Biofouling, 19:123-131.

Gracia, C.A.; Rangel-Buitrago, N.; Oakley, J.A.; Williams, A. (2017) Use of ecosystems in coastal erosion management. Ocean and Coastal Management, https://doi.org/10.1016/j.ocecoaman.2017.07.009

Graham, N.; Gruner, D.; Lim, J.; Gillespie, R. (2017) - Island ecology and evolution: Challenges in the Anthropocene. Environmental Conservation, 44:323-333.

Güreşen, A.; Pergent, G.; Güreşen, S.0.; Aktan, Y. (2020) - Evaluating the coastal ecosystem status of two Western and Eastern Mediterranean islands using the seagrass Posidonia oceanica. Ecological Indicators 108:105734.

Guyader, 0.; Bellanger, M.; Reynal, L.; Demanèche, B.; Berthou, P. (2013) - Fishing strategies, economic performance and management of moored fishing aggregation devices in Guadeloupe. Aquatic Living Resources, 26(1):97-105.

Halpern, S. et al. (2015) - Spatial and temporal changes in cumulative human impacts on the world's ocean. Nature Communications, 6 : 7615.

Hay, J.E. (2013) - Small island developing states: coastal systems, global change and sustainability. Sustainability Science 8:309-326.

Helmus, M.R.; Mahler, D.L.; Losos, J.B. (2014) - Island biogeography of the Anthropocene. Nature, 513:543-546.

Hernández, J.C.; Clemente, S.; Sangil, C.; Brito, A. (2008) - The key role of the sea urchin Diadema aff. antillarum throughout the Canary Islands (eastern subtropical Atlantic) in controlling macroalgae assemblages: an spatio-temporal approach. Marine Environmental Research, 66:259-270.

Herrera, A.; Asensio, M.; Martínez, I.; Santana, A.; Packard, T.; Gómez, M. (2018) - Microplastic and tar pollution on three Canary Islands beaches: An annual study. Marine Pollution Bulletin, 129:494-502.

Hughes, T.P.; Keller, B.D.; Jackson, J.B.C.; Boyle, M.J. (1985) - Mass mortality of the echinoid Diadema antillarum Philippi in Jamaica. Bulletin of Marine Science, 36:377-384. 
Hunt, T.L. (2007) - Rethinking Easter Island's ecological catastrophe. Journal of Archaeological Science, 34(3):485-502.

Imhof, H.K.; Sigl, R.; Brauer, E.; Feyl, S.; Giesemann, P.; Klink, S.; Leupolz, K.; Löder, M.G.J.; Löschel, L.A.; Missun, J.; Muszynski, S.; Ramsperger, A.F.R.M.; Schrank, I.; Speck, S.; Steibl, S.; Trotter, B.; Winter, I.; Laforsch, C. (2017) - Spatial and temporal variation of macro-, meso- and microplastic abundance on a remote coral island of the Maldives, Indian Ocean. Marine Pollution Bulletin 116(12):340-347.

IPCC. (2014) - Cambio climático 2014: Informe de síntesis. Contribución de los Grupos de trabajo I, II y III al Quinto Informe de Evaluación del Grupo Intergubernamental de Expertos sobre el Cambio Climático [Equipo principal de redacción, R.K. Pachauri y L.A. Meyer (eds.)]. IPCC, Ginebra, Suiza, 157 p.

ISTAC (Canary Islands Statistics Bureau). (2017) - Expedientes abiertos por la Agencia de Protección del Medio Urbano y Natural (APMUN) según tipos de infracción por islas de Canarias y periodos. Canary Islands, Spain. http://www.gobiernodecanarias.org/istac/.

Jentoft, S.; Pascual-Fernandez, J.J.; De la Cruz, R.; Gonzalez-Ramallal, M.; Chuenpagdee, R. (2012) - What stakeholders think about marine protected areas: case studies from Spain. Human Ecology, 40:185-197.

Jiménez-Alvarado, D. (2010) - Impact of recreational fishing on fishery resources of the Canary Islands. MS Thesis, University of Las Palmas de Gran Canaria.

Kam, L.E.; Leung, P.S.; Ostrowski, A.C. (2003) - Economics of offshore aquaculture of Pacific threadfin (Polydactylus sexfilis) in Hawaii. Aquaculture, 223:63-87.

Kier, G.; Kreft, H.; Lee, T.M.; Jetz, W.; Ibisch, P.L.; Nowicki, C.; Barthlott, W. (2009) - A global assessment of endemism and species richness across island and mainland regions. Proceedings of the National Academy of Sciences, 106:9322-9327.

Kueffer, C.; Kinney, K. (2017) - What is the importance of islands to environmental conservation? Environmental Conservation, 44:311-322.

La Daana, K.K.; Officer, R.; Lyashevska, 0., Thompson, R.C.; O'Connor, I. (2017) - Microplastic abundance, distribution and composition along a latitudinal gradient in the Atlantic Ocean. Marine Pollution Bulletin, 115:307-314.

Lessios, H.A. (2016) - The great Diadema antillarum die-off: 30 years later. Annual Review of Marine Science, 8:267-283.

Ling S.D.; Sinclair, M.; Levi, C.J.; Reeves, S.E.; Edgar, G.J. (2017). Ubiquity of microplastics in coastal seafloor sediments. Marine Pollution Bulletin 121(1-2):104-110.

Magera, A.M.; Mills Flemming, J.E.; Kaschner, K.; Christensen, L.B.; Lotze, H.K. (2013) - Recovery Trends in Marine Mammal Populations. PLoS ONE, 8(10): e77908. https://doi.org/10.1371/journal.pone.0077908.
Manrique de Lara, D.R.; Corral, S. (2017) - Local community-based approach for sustainable management of artisanal fisheries on small islands. Ocean and Coastal Management 142:150-162.

Martín, J.L. (2010) - Atlas de biodiversidad de Canarias. Ed. Gobierno de Canarias, 287 pp.

Martínez-Saavedra, J. (2011) - Análisis del estado de los recursos pesqueros de Gran Canaria a partir del estudio de series históricas de capturas. MS Thesis. University of Las Palmas de Gran Canaria, 32 pp.

Martín-García, L. (2013) - La distribución espacial de las comunidades bentónicas infralitorales de Canarias y su importancia en la gestión del medio marino. PhD Thesis, University of La Laguna, 245 pp.

Martín-García, L.; Herrera, R.; Moro-Abad, L.; Sangill, C.; Barquín-Díez, J. (2014) - Predicting the potential habitat of the harmful cyanobacteria Lyngbya majuscula in the Canary Islands (Spain). Harmul Algae, 34:76-86.

Martins, G.; Jenkins, S.R.; Neto, A.l.; Hawkins, S.; Thompson, R.C. (2016) - Long-term modifications of coastal defences enhance marine biodiversity. Environmental Conservation, 443:109-116.

Mimura, N.; Nunn, P.D. (1998) - Trends of beach erosion and shoreline protection in rural Fiji. Journal of Coastal Research 14(1):37-46.

Minchin, D. (2012) - Rapid assessment of the bryozoan, Zoobotryon verticillatum (Delle Chiaje, 1822) in marinas, Canary Islands. Marine Pollution Bulletin, 64:2146-2150.

Ministerio de Agricultura, Alimentación y Medio Ambiente (MAGRAMA). (2012) - Estrategia marina. Demarcación marina canaria Parte IV. Descriptores del buen estado ambiental. Descriptor 2: Especies alóctonas. Evaluación inicial y buen estado ambiental. Ministerio de Agricultura, Alimentación y Medio Ambiente. Secretaría General Técnica. Centro de Publicaciones. Madrid, 73 pp.

Molnar, J.L.; Gamboa, R.L.; Revenga, C.; Spalding, M.D. (2008) Assessing the global threat of invasive species to marine biodiversity. Frontiers in Ecology and Environment, 6:485-492.

Monteiro, R.; Ivar do Sul, J.A.; Costa, M.F. (2018) - Plastic Pollution in Oceanic Islands of the Atlantic Ocean. Environmetal Pollution, 238:103-110.

Mumby, P.J.; Hedley, J.D.; Zychaluk, K.; Harborne, A.R.; Blackwell, P.G. (2006) - Revisiting the catastrophic die-off of the urchin Diadema antillarum on Caribbean coral reefs: Fresh insights on resilience from a simulation model. Ecological Modelling, 196:131-148.

Myers, N.; Mittermeier, R.A.; Mittermeier, C.G.; da Fonseca, G.A.; Kent, J. (2000) - Biodiversity hotspots for conservation priorities. Nature, 403:853-858.

Nagai, S.; Yoshida, G.; Tarutani, K. (2011) - Changes in species composition and distribution of algae in the coastal waters of western Japan. In: Casalengno, S. (Ed.), Global warming impacts - case studies on the economy, human health, and on urban and natural environments. InTech, Shanghai: 209-236. 
Ng, K.; Phillips, M.R.; Calado, H.; Borges, P.; Veloso-Gomes, F. (2013) - Seeking harmony in coastal development for small islands: Exploring multifunctional artificial reefs for São Miguel Island, the Azores. Applied Geography, 44:99-111.

Nunn, P.D.; Veitayaki, J.; Ram-Bidesi, V.; Vunisea, A. (1999) - Coastal issues for oceanic islands: implications for human futures. Natural Resources Forum, 23:195-207.

Nunn, P.D; Kumar, L; Eliot, I.; McLean, R.F. (2016) - Classifying Pacific islands. Geoscience Letters 3:7. https://doi.org/10.1186/s40562-016-0041-8

Occhipinti-Ambrogi, A.; Savini, D. (2003) - Biological invasions as a component of global change in stressed marine ecosystems. Marine Pollution Bulletin, 46:452-551.

Ory, N.; Chagnon, C.; Felix, F.; Fernández, C.; Ferreira, J.L.; Gallardo, C.; Garcés Ordóñez, 0.; Henostroza, A.; Laaz, E.; Mizraji, R.; Mojica, H.; Murillo Haro, V.; Medina, L.0.; Preciado, M.; Sobral, P.; Urbina, M.A.; Thiel, M. (2018) - Low prevalence of microplastic contamination in planktivorous fish species from the southeast Pacific Ocean. Marine Pollution Bulletin, 127:211-216.

Otto, R.; Krüsi, B.0.; Kienast, F. (2007) - Degradation of an arid coastal landscape in relation to land use changes in Southern Tenerife (Canary Islands). Journal of Arid Environments, 70:527-539.

Parmesan, C. (2006) Ecological and evolutionary responses to recent climate change. Annual Review of Ecology, Evolution and Systematics, 27:637-669.

Parrilla, G.; Lavín, A.; Bryden, H.L.; García, M.; Millard, R. (1994) Rising temperatures in the Subtropical N. Atlantic over the past 35 years. Nature, 369:48-51.

Piacenza, S.E.; Balazs, G.H.; Hargrove, S.; Richards, P.M.; Heppell, S.S. (2016) - Trends and variability in demographic indicators of a recovering population of green sea turtles Chelonia mydas. Endangered Species Research, 31(1):103-117.

Relini, G.; Relini, M.; Torchia, G.; De Angelis, G. (2002) - Trophic relationships between fishes and an artificial reef. ICES Journal of Marine Science, 59:36-42.

Riera, R.; Becerro, M.; Ramos, E.; Monterroso, 0.; Rodríguez, M. (2013) - Response of different benthic habitats to off-shore fish cages. Aquaculture Research, 46:1490-1500.

Riera, R.; Becerro, M.A.; Stuart-Smith, R.D.; Delgado, J.D.; Edgar, G. (2014) - Out of sight: out of mind: Threats to the marine biodiversity of the Canary Islands (NE Atlantic Ocean). Marine Pollution Bulletin, 86:9-18.

Riera, R.; Delgado, J.D. (2019) - Canary Islands. Pp. 483-500. In: World Seas: an Environmental Evaluation. Academic Press.

Riera, R.; Núñez, J.; Martín, D. (2011a) - Effects of thermal pollution on the soft-bottoms surrounding of a power station in the Canary Islands (NE Atlantic Ocean). Oceanology, 51:1040-1046.
Riera, R.; Pérez, 0.; Álvarez, 0.; Simón, D.; Díaz, D.; Monterroso, 0.; Núñez, J. (2016) - Clear regression of harvested intertidal mollusks. A 20-year (1994-2014) comparative study. Marine Environmental Research, 113:56-61.

Riera, R.; Sánchez-Jerez, P.; Rodríguez, M.; Monterroso, 0. (2014) Artificial marine habitats favor a single fish species on a long-term scale: the dominance of Boops boops around off-shore fish cages. Scientia Marina, 78:505-510.

Riera, R.; Sangil, C.; Sansón, M. (2015) - Long-term herbarium data reveal the decline of a temperate-water algae at its southern range. Estuarine, Coastal and Shelf Science, 165:159-165.

Riera, R.; Tuset, V.; Monterroso, 0.; Rodríguez, M. (2017) - Analyzing functional indices to determine the effects of fish cages farms in insular coastal assemblages. Aquaculture, 479:384-395.

Riera, R.; Tuya, F.; Ramos, R.; Rodríguez, M.; Monterroso, 0. (2012) - Variability of macrofaunal assemblages on the surroundings of brine disposal. Desalination, 291:94-100.

Riera, R.; Tuya, F.; Sacramento, A.; Ramos, E.; Rodríguez, M.; Monterroso, 0. (2011b) - The effects of brine disposal on a subtidal meiofauna community. Estuarine, Coastal and Shelf Science, 93:359-365.

Rivers, G.; Edmunds, P. (2001) - Mechanisms of interaction between macroalgae and scleractinians on a coral reef in Jamaica. Journal of Experimental Marine Biology and Ecology, 261:159-172.

Roberts, C.M. et al. (2002) - Marine biodiversity hotspots and conservation priorities for tropical reefs. Science, 295:1280-1284.

Ruiz, G.M. (2000) - Global spread of microorganisms by ships: Ballast water discharge from vessels harbors a cocktail of potential pathogens. Nature, 408:49-50.

Russell, J.C.; Meyer, J-Y.; Holmes, N.D.; Pagad, S. (2017) - Invasive alien species on islands: impacts, distribution, interactions and management. Environmental Conservation, 44:359-370.

Sánchez Rodríguez, A.; Rodrigo Sanz, M.; Betancort Rodríguez, J.R. (2015) - Occurrence of eight UV filters in beaches of Gran Canaria (Canary Islands). An approach to environmental risk assessment. Chemosphere, 131:85-90.

Sangil, C.; Sansón, M.; Afonso-Carrillo, J.; Herrera, R.; Rodríguez, A.; Martín-García, L.; Díaz-Villa, T. (2012) - Changes in subtidal assemblages in a scenario of warming: Proliferations of ephemeral benthic algae in the Canary Islands (eastern Atlantic Ocean). Marine Environmental Research, 77:120-128.

Santos, R.; de Castro, M; Gómez-Gesteira, M.; Álvarez, I. (2012) - Differential in coastal and oceanic SST warming rates along the Canary upwelling ecosystems from 1982 to 2010. Continental Shelf Research, 47:1-6.

Semeoshenkova, V.; Newton, A. (2015) - Overview of erosion and beach quality issues in three Southern European countries: Portugal, Spain and Italy. Ocean and Coastal Management, 118:12-21. 
Serranti, S.; Palmieri, R.; Bonifazi, G.; Cózar, A. (2018) - Characterization of microplastic litter from oceans by an innovative approach based on hyperspectral imaging. Waste Management, 76:117-125.

Sheehy, D.J.; Vik, S.F. (2010) - The role of constructed reefs in nonindigenous species introductions and range expansions. Ecological Engineering, 36:1-11.

Simberloff, D. (1995) - Why Do Introduced Species Appear to Devastate Islands More Than Mainland Areas? Pacific Science, 49:87-97.

Sistiaga, Y. (2011) - Evolución del poder de pesca en la isla de Gran Canaria: repercusiones ambientales y su impacto sobre los recursos pesqueros. MS Thesis, University of Las Palmas de Gran Canaria, 51 pp.

SPREP (Secretariat of the Pacific Regional Environment Programme). 2016. State of consenvation in Oceania. Regional report 2013. 167 p.

Sundblad, G.; Bergström, U. (2014) - Shoreline development and degradation of coastal fish reproduction habitats. Ambio, 43(8):10201028.

Thistlethwaite, R.; Votaw, G. (1992) - Environment and Development: A Pacific Island Experience. Asian Development Bank, Manila.

Tovar, B.; Hernández, R.; Rodríguez-Déniz, H. (2015) - Container port competitiveness and connectivity: The Canary Islands main ports case. Transport Policy, 38:40-51.

Tuya, F.; Boyra, A.; Sánchez-Jerez. P.; Barberá, C.; Haroun, R.J. (2004) - Relationships between rocky-reef fish assemblages, the sea urchin Diadema antillarum and macroalgae throughout the Canarian archipelago. Marine Ecology Progress Series, 278:157-169.

Tuya, F.; Hernández-Zerpa, H.; Espino, F.; Haroun, R. (2013) - Drastic decadal decline of the seagrass Cymodocea nodosa at Gran Canaria (Eastern Atlantic): Interactions with the green algae Caulerpa prolifera. Aquatic Botany, 105:1-6.

Tuya, F.; Png-González, J.; Riera, R.; Haroun, R.; Espino, F. (2014a) Ecological structure and function differs between habitats dominated by seagrasses and green seaweeds. Marine Environmental Research, 98:1-13.
Valiela, I.; McClelland, J.; Hauxwell, J.; Behr, P.J.; Hersh, D.; Foreman, K. (1997) - Macroalgal blooms in shallow estuaries: Controls and ecophysiological and ecosystem consequences. Limnology and Oceanography, 42:1105-1118.

Vergés, A.; Steinberg, P.D.; Hay, M.E., et al. (2014) - The tropicalization of temperate marine ecosystems: Climate-mediated changes in herbivory and community phase shifts. Proc. Biol. Sci., 281(1789):20140846.

Wallentinus, I.; Nyberg, C.D. (2007) - Introduced marine organisms as habitat modifiers. Marine Pollution Bulletin, 55:323-332.

Ware, C.; Berge, J.; Sundet, J.H.; Kirkpatrick, J.B.; Coutts, A.D.M.; Jelmert, A.; Olsen, S.M.; Floerl, 0.; Wisz, M.S.; Alsos, I.G. (2014) - Climate change, non-indigenous species and shipping: assessing the risk of species introduction to a high-Arctic archipelago. Diversity and Distribution, 20:10-19.

Waycott, M.; Duarte, C.M.; Carruthers, T.J.B.; et al., 2009. Accelerating loss of seagrasses across the globe threatens coastal ecosystems. Proc. Natl. Acad. Sci. U.S.A., 106:12377-12381.

Whitakker, R.J.; Fernández-Palacios, J.M. (2007) - Island Biogeography, Ecology, Evolution and Conservation. Oxford Biology (ed.), New York, EEUU, $401 \mathrm{pp}$.

Williams, S.L. (2007) - Introduced species in seagrass meadows: Status and concerns. Journal of Experimental Marine Biology and Ecology, 350:89-110.

Wong, P.P.; Marone, E.; Lana, P.; Fortes, M.; Moro, D.; Agard, J.; Vicente, L. (2005) - Island systems. In: Hassan R, Scholes R, Ash N, eds. Ecosystems and Human Well-Being: Current State and Trends: Findings of the Condition and Trends Group (The Millennium Ecosystem Assessment, Vol. 1). Washington, DC; Island Press, pp. 663-680.

Zeller, D.; Darcy, M.; Booth, S.; Lowe, M.K.; Martell, S. (2008) - What about recreational catch? Potential impact on stock assessment for Hawaii's bottomfish fisheries. Fisheries Research, 91:88-97.

Zylich, K., et al (2014) Fishing in Eastern Island, a recent history (19502010). Latin American Journal of Aquatic Research, 42(4):845-856. 